\title{
Complete removable dentures manufacturing in CAD/CAM: literature review
}

\section{Wykonanie protez całkowitych w technologii CAD/CAM \\ - przegląd piśmiennictwa}

\section{Edyta Cywoniuk ${ }^{1}$, Teresa Sierpińska ${ }^{2}$, Magdalena Sulewska ${ }^{3}$}

${ }^{1}$ Laboratorium Techniczne, ZirkonZahn Polska

${ }^{2}$ Katedra Protetyki Stomatologicznej, Uniwersytet Medyczny w Białymstoku

Department of Prosthodontics, Medical University in Bialystok

Head: prof. dr hab. n. med. Teresa Sierpińska

${ }^{3}$ Zakład Chorób Przyzębia i Błony Śluzowej Jamy Ustnej, Uniwersytet Medyczny w Białymstoku Department of Periodontal and Oral Mucosa Diseases, Medical University of Bialystok Head: prof. dr hab. n. med. Małgorzata Pietruska

KEY WORDS:

complete dentures, CAD/CAM

\section{Summary}

Complete dentures are the first mainstay choice of edentulous patients. For financial reasons, most of the edentate patients still use traditional acrylic full dentures. However, a lot of studies have indicated that CAD/CAM complete denture manufacturing has substantially increased in volume in the past decade. The aim of this study was to analyze the literature in the field of manufacturing complete removable dentures in $C A D / C A M$ using rapid prototyping $(R P)$ of 2-visit protocol. An electronic search was performed in the PubMed and Google Scholar databases from 1995 to 2020 using a variety of key words, including: complete removable dentures, digital complete dentures, CAD design, $3 D$ print. Thirty articles related to the topic were selected. It was found that technological developments of CAD/ $C A M$ and RP enabled digital planning and manufacturing of complete removable dentures from start to finish.
HASŁA INDEKSOWE:

protezy całkowite, CAD/CAM

\section{Streszczenie}

Wykonanie protez calkowitych jest metoda $z$ wyboru podczas leczenia pacjentów z bezzębiem. Z powodów finansowych większość bezzębnych pacjentów nadal użytkuje tradycyjne, akrylowe protezy calkowite. Jednakże wiele badań wskazuje, iż liczba protez catkowitych, wykonywanych w technologii CAD/CAM istotnie wzrasta $w$ ostatnich latach. Celem pracy byta analiza piśmiennictwa dotyczacego wykonawstwa ruchomych protez catkowitych $w$ systemie CAD/CAM z wykorzystaniem protokotu dwuwizytowego. W tym calu przeszukano bazy piśmiennictwa: PubMed $i$ Google Scholar za lata 19952020 stosujac stowa kluczowe: ruchome protezy calkowite, cyfrowe protezy calkowite, projektowanie CAD, druk $3 D$. Ostatecznie do przegladu zakwalifikowano trzydzieści artykułów spetniajacych kryteria. Stwierdzono, że rozwój technologiczny systemów CAD/CAM oraz systemów szybkiego przetwarzania umożliwia cyfrowe planowanie oraz wykonanie protez catkowitych od rozpoczęcia leczenia do jego zakończenia. 
Edentulism is a serious health problem in industrialized countries due to an aging population and in developing countries due to poor oral hygiene. ${ }^{1}$ An estimated $26 \%$ of seniors in the U.S. suffer from edentulism, and the edentulous senior population ranges from $15 \%$ to $78 \%$ in Europe, $24 \%$ in Indonesia, $11 \%$ in China, and 23\% in Brazil. ${ }^{2}$ According to the Medical University of Bialystok, about $40 \%$ of seniors in Poland are edentulous. ${ }^{3}$

Felton et al. showed that despite advances in dental science, the total number of edentulous patients has not decreased. ${ }^{4}$ Dentition with proper function and aesthetics is essential for one' $\mathrm{s}$ well-being and quality of life. Complete removable dentures are the first choice when it comes to edentate patients. Due to financial constraints, most edentulous patients still rely on acrylic complete denture solutions. Despite a projected decrease in the age-specific prevalence of edentulism, it is believed that the demand for complete removable dentures will increase in the next decades. ${ }^{5}$ The conventional technique for making complete removable dentures has been used for more than half a century and can be considered a proven gold standard procedure. However, conventional methods of fabricating complete removable dentures require multiple visits and lengthy laboratory procedures. Each of these steps entails a significant involvement of the clinician and technician, which can lead to fabrication errors, inaccuracies, increased treatment time and costs. Typically, five visits are required for the fabrication of conventional complete removable dentures, from initial impressions to ready-to-use denture. ${ }^{6}$ However, despite many visits, edentulous patients complain of problems stabilizing dentures in the mouth. This may result from atrophy of the prosthetic base or impaired neuromuscular control. ${ }^{7}$

In the standard protocol, full dentures are made of polymethyl methacrylate (PMMA)
Bezzębie stanowi poważny problem zdrowotny w krajach uprzemysłowionych ze względu na starzenie się populacji, zaś w krajach rozwijających się ze względu na słabą higienę jamy ustnej. ${ }^{1}$ Szacuje się, że 26\% seniorów w USA cierpi na bezzębie, a bezzębna populacja seniorów wynosi od $15 \%$ do $78 \%$ w Europie, 24\% w Indonezji, 11\% w Chinach i $23 \%$ w Brazylii. ${ }^{2}$ Według Uniwersytetu Medycznego w Białymstoku bezzębnych seniorów jest w Polsce około 40\%. ${ }^{3}$

Felton i wsp. wykazali, że pomimo postępów w nauce o stomatologii, całkowita liczba pacjentów, u których dochodzi do bezzębia, nie zmniejszyła się. ${ }^{4}$ Uzębienie o odpowiedniej funkcji i estetyce jest niezbędne dla dobrego samopoczucia i zapewnienia odpowiedniej jakości życia. Protezy całkowite są pierwszym wyborem jeśli chodzi o pacjentów bezzębnych. Ze względu na ograniczenia finansowe większość pacjentów bezzębnych nadal korzysta z rozwiązań protetycznych w postaci akrylowych protez całkowitych. Pomimo przewidywanego spadku częstości występowania bezzębia w zależności od wieku, uważa się, że zapotrzebowanie na protezy całkowite będzie rosło w następnych dziesięcioleciach. ${ }^{5}$ Konwencjonalna technika wykonania protez całkowitych jest stosowana od ponad pół wieku i może być uważana za sprawdzoną procedurę złotego standardu. Konwencjonalne metody wykonywania protez całkowitych wymagają jednak wielu wizyt i długotrwałych procedur laboratoryjnych. Każdy z tych etapów wymaga znacznego zaangażowania lekarza i technika, co może prowadzić do błędów w wykonaniu, niedokładności oraz wydłużenia czasu leczenia oraz wzrostu kosztów. Zwykle do wykonania konwencjonalnych protez całkowitych wymagane jest 5 wizyt, od wstępnych wycisków do oddania protezy. ${ }^{6}$ Jednak mimo wielu wizyt bezzębni pacjenci skarżą się na problemy ze stabilizacją protez w jamie ustnej. Może to być spowodowane zanikiem podłoża protetycznego lub osłabioną kontrolą nerwowo-mięśniową. ${ }^{7}$ 
and include a hot polymerization process. $^{8}$ The fabrication of complete removable dentures using computer-aided design and manufacturing (CAD/CAM) methods was first documented in the 1990s. ${ }^{9-10}$ The number of such procedures has increased significantly over the last decade. The clinical success in terms of patient satisfaction and the degree of fit of CAD/CAM fabricated complete dentures to the prosthetic base has been reported in many scientific papers. ${ }^{9-12}$

The purpose of this study was to analyze the literature on $\mathrm{CAD} / \mathrm{CAM}$ fabrication of removable fentures using a two-visit protocol. The electronic databases PubMed and Google Scholar were analyzed for the years 1995-2020. Key words entered included: complete removable dentures, digital complete dentures, CAD design, 3D print. Documented developments, techniques, advantages and disadvantages of CAD/CAM systems in the fabrication of complete removable dentures were summarized in 120 publications. For the main topic, abstracts of 60 articles were analyzed, from which 30 articles similar in topic were selected for detailed review. ${ }^{13-14}$ Case studies were excluded from the analysis.

After reviewing the included publications, it was concluded that technological developments in CAD/CAM systems allow for digital planning and fabrication of complete removable dentures. However, these methods have several limitations, which will be addressed in the following analysis.

The use of CAD/CAM systems in the fabrication of complete dentures has been limited until recently due to the lack of appropriate CAD software. ${ }^{15-24}$ Digitally fabricated complete removable dentures had insufficient mechanical properties, such as strength, and were deemed useless for patients. ${ }^{25}$ The technology has been modified and improved with the capabilities of the latest software modules. CAD/CAMengineered dentures have been found to have
W standardowym protokole postępowania protezy całkowite wykonywane są z polimetakrylanu metylu (PMMA) i obejmują proces polimeryzacji na gorąco. ${ }^{8}$ Wykonanie protez całkowitych metodami komputerowego projektowania i wytwarzania (CAD/CAM) zostało po raz pierwszy udokumentowane w latach dziewięćdziesiątych $\mathrm{XX}$ wieku. ${ }^{9-10} \mathrm{~W}$ ciągu ostatniej dekady liczba takich procedur znacznie wzrosła. Sukces kliniczny pod względem zadowolenia pacjentów oraz stopnia dopasowania protez całkowitych do podłoża protetycznego, wytwarzanych metodą CAD/CAM został opisany w wielu publikacjach naukowych. ${ }^{9-12}$

Celem pracy była analiza piśmiennictwa z zakresu wykonania protez ruchomych w systemach CAD/CAM z wykorzystaniem protokołu 2 wizyt. Elektroniczne bazy PubMed i Google Scholar analizowano dla lat 1995-2020. Wprowadzono słowa kluczowe, m.in.: protezy ruchome, cyfrowe protezy całkowite, projektowanie CAD, druk 3D. Udokumentowane osiągnięcia, techniki, zalety i wady systemów CAD/CAM w wykonawstwie całkowitych protez ruchomych zostały podsumowane w 120 publikacjach. W przypadku tematu głównego przeanalizowano streszczenia 60 artykułów, spośród których wybrano do szczegółowej analizy 30 artykułów zbliżonych tematycznie. ${ }^{13-14}$ Opisy przypadków wyłączono z analizy.

Po zapoznaniu się z włączonymi do analizy publikacjami stwierdzono, że rozwój technologiczny systemów CAD/CAM pozwala na cyfrowe planowanie i wykonanie ruchomych protez całkowitych. Jednak metody te mają kilka ograniczeń, co zostanie uwzględnione w poniższej analizie.

Stosowanie systemów CAD/CAM w wykonawstwie protez całkowitych było do niedawna ograniczone ze względu na brak odpowiedniego oprogramowania CAD. ${ }^{15-24}$ Protezy całkowite wykonane cyfrowo miały niewystarczające właściwości mechaniczne, takie jak wytrzymałość, i zostały uznane za bezużyteczne 
reduced resin volume and weight compared to conventional dentures, which may increase patient comfort and adaptability. ${ }^{26}$ The dentures are milled from PMMA blocks. The denture plate is milled from pink PMMA block and the teeth are milled from PMMA resin with improved material properties. 3D print with $3 \mathrm{D}$ printers is also possible. The lack of polymerization shrinkage improves the fit of the denture and ultimately allows for its better

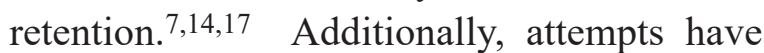
been made to develop or improve software for digital modeling and milling of denture plates. $^{27}$

By collecting data and transferring it into 1:1 design software, highly customized restorations can be fabricated exclusively in a digital protocol, reducing the number of fabrication steps and improving communication between patient and dentist.

Digital complete dentures can be fabricated in two ways: completely digital starting with taking an impression using an intraoral scanner, which has numerous disadvantages in the case of an edentulous prosthetic base. The other way is to take a standard functional impression and record the central occlusion, then scan and proceed digitally, which can provide higher precision and fit of the long-term prosthetic restoration. ${ }^{2,4,20}$

$\mathrm{CAD} / \mathrm{CAM}$ technology reduces dental technician time by milling restorations inhouse, increases product quality in terms of precision, gives control over work steps, and eliminates physical barriers by simplifying data exchange within the treatment team. ${ }^{27,28}$ Modern computer methods allow for the rapid and accurate creation of a virtual prosthesis design. The procedure usually begins with a work plan, diagnosis, description and registration of the patient in the software. Next, plaster models of the maxilla and mandible must be scanned, central occlusion registered, or digital models generated from dla pacjentów. ${ }^{25}$ Technologia została zmodyfikowana i ulepszona dzięki możliwościom najnowszych modułów oprogramowania. Stwierdzono, że w porównaniu z protezami konwencjonalnymi protezy wykonane $\mathrm{z}$ zastosowaniem systemów CAD/CAM mają zmniejszoną objętość i masę żywicy, co może zwiększyć komfort i zdolność adaptacji pacjentów. ${ }^{26}$ Protezy są frezowane $\mathrm{z}$ bloczków PMMA. Płyta protezy jest frezowana $\mathrm{z}$ różowego bloczka PMMA, a zęby z żywicy PMMA o ulepszonych właściwościach materiałowych. Możliwe jest również drukowanie przestrzenne w drukarkach 3D. Brak skurczu polimeryzacyjnego poprawia dopasowanie protezy i ostatecznie pozwala na lepszą retencję.7,14,17 Dodatkowo podejmowano próby rozwijania lub ulepszania oprogramowania w celu cyfrowego modelowania $\mathrm{i}$ frezowania płyt protez. ${ }^{27}$

Gromadzenie danych i ich przeniesienie do oprogramowania projektowego 1:1, umożliwia wykonanie wysoce zindywidualizowanych uzupełnień wyłącznie w protokole cyfrowym, co pozwala na skrócenie liczby etapów wykonania i poprawia komunikację pomiędzy pacjentem i lekarzem dentystą.

Protezy całkowite wykonane w technologiach cyfrowych można wykonać na dwa sposoby: całkowicie cyfrowo zaczynając od pobrania wycisku przy użyciu skanera wewnątrzustnego, który w przypadku bezzębnego podłoża protetycznego posiada liczne wady. Innym sposobem jest pobranie standardowego wycisku czynnościowego i rejestracji zwarcia centralnego, następnie zeskanowanie i kontynuacja pracy cyfrowo, co może zapewnić wyższą precyzję i dopasowanie długoczasowego uzupełnienia protetycznego. $2,4,20$

Technologia CAD/CAM skraca czas pracy techników dentystycznych poprzez frezowanie uzupełnień we własnym zakresie, zwiększa jakość produktu pod względem precyzji, daje możliwość kontroli nad etapami pracy oraz eliminuje fizyczne bariery poprzez uproszczenie 
"STL" files if a digital impression was taken. A very important step when planning and designing a prosthetic work for a patient with extensive deficiencies is to determine the occlusal plane. To avoid repeat visits by the patient to the office, digital data from the office and virtual articulation should be used. The technician should use software that will allow the patient's facial images and DICOM files to be entered into the computer. Assuming that the occlusal plane is parallel to the Ala - Tragus line (antilobium - flare of the nostrils), the patient's facial scan or 2D photo should be placed in the virtual articulator, the facial image should be combined with the previously scanned prosthetic base and scanned jaw models created from STL files, the DICOM photo should be attached, and the virtual occlusal plane should be determined. A modern dental office, equipped with a Plane Finder $\AA$, facial arch or axiograph should provide data with recorded facial asymmetry that the technician can transfer to the articulator. For correct fabrication of a digital prosthesis, it is necessary to mark many points, reference planes, which requires properly trained personnel.

Digital modeling steps:

- indicating the papilla incisiva, maxilla tuberosity and median line on the upper jaw model,

- positioning of the labial plane/horizontal plane of the maxilla,

- determination of the canine tooth position on the occlusal rim (using nasal width measurements),

- defining the initial location of the first maxillary premolars,

- marking points of pterygopharyngeal plica on the right and left side of the maxilla,

- indication of the right and left buccal frenum on digital mandibular model, wymiany danych w obrębie zespołu terapeutycznego. ${ }^{27,28}$ Nowoczesne metody komputerowe pozwalają na szybkie i dokładne stworzenie projektu wirtualnej protezy. Postępowanie zwykle rozpoczyna się od planu pracy, rozpoznania, opisu i rejestracji pacjenta w programie. Następnie należy zeskanować modele gipsowe szczęki i żuchwy, zarejestrować zwarcie centralne lub wygenerować modele cyfrowe z plików „STL” jeśli pobrano wycisk cyfrowy. Bardzo ważnym etapem podczas planowania i projektowania pracy protetycznej dla pacjenta z rozległymi brakami jest określenie płaszczyzny zwarcia. Aby uniknąć powtórnych wizyt pacjenta $\mathrm{w}$ gabinecie należy korzystać $\mathrm{z}$ danych cyfrowych $\mathrm{z}$ gabinetu oraz $\mathrm{z}$ wirtualnej artykulacji. Technik powinien korzystać z oprogramowania, które pozwoli wprowadzić do komputera zdjęcie twarzy pacjenta i pliki DICOM. Wychodząc z założenia, że płaszczyzna zwarcia jest równoległa do linii Ala Tragus (skrawek ucha - skrzydełko nosa), należy umieścić skan twarzy pacjenta lub zdjęcie 2D w wirtualnym artykulatorze, połączyć obraz twarzy z wcześniej zeskanowanym podłożem protetycznym i zeskanowanymi modelami szczęki, utworzonymi z plików STL, dołączyć zdjęcie DICOM i wyznaczyć wirtualną płaszczyznę zwarcia. Nowoczesny gabinet stomatologiczny, wyposażony w Plane Finder ${ }^{\circledR}$, łuk twarzowy czy aksjograf powinien dostarczyć dane z zarejestrowaną asymetrią twarzy, które technik będzie mógł przenieść do artykulatora. Aby prawidłowo wykonać protezę cyfrową konieczne jest zaznaczenie wielu punktów, płaszczyzn odniesienia, co wymaga odpowiednio przeszkolonego personelu.

Etapy cyfrowego modelowania:

- wskazanie brodawki przysiecznej, wyniosłości szczęki oraz linii środkowej na modelu szczęki,

- ustawienie płaszczyzny wargowej/poziomej płaszczyzny szczęki,

- określenie położenia kłów na wale 
- defining the initial position of the first premolars of the mandible,

- marking the frenum and retromolar pad on the mandibular model,

- determining the midline and the top of the occlusal rim,

- positioning of the horizontal plane of the mandible,

- indicating the shape and length of the occlusal rim,

- verification and correction (if necessary) of the position of the first molars, which are automatically placed in the lowest point of the process,

- marking points on the occlusal rim to define the distal surface of the second molars,

- defining the shape and length of the occlusal rim,

- examination, confirmation or correction of the previously indicated lines and points on both models,

- selection of the tooth shape and size from the virtual library,

- addition of molars (possible removal or introduction of second molars depending on the condition of the oral cavity),

- addition of anterior teeth and verification of their position in accordance with the occlusal plane (possible modification),

- determination of the ratio between upper and lower teeth using the "chain model" to change their position on the occlusal rim,

- planning the insertion direction for future reconstruction by blocking out undercuts,

- determining the extent and digital modeling of the final shape and esthetics of the mandibular and maxillary denture plate,

- fusion of teeth to the denture plate and preparation for milling.

Recently, it has become very common to design a prosthetic restoration based on the DSD (Digital Smile Design) protocol. The treatment wzornika zwarciowrego (poprzez pomiar szerokości nosa),

- określenie początkowej lokalizacji pierwszych przedtrzonowców szczęki,

- zaznaczanie punktów fałdu skrzydłowo-gardłowego po prawej i lewej stronie szczęki,

- wskazanie prawego i lewego wędzidełka policzkowego na cyfrowym modelu żuchwy,

- określenie początkowej pozycji pierwszych zębów przedtrzonowych żuchwy,

- zaznaczenie wędzidełka i trójkąta zatrzonowcowego na modelu żuchwy,

- określenie linii środkowej oraz szczytu wału wzornika zwarciowego szczęki,

- ustawienie płaszczyzny poziomej żuchwy,

- wskazanie kształtu i długości wału wzornika zwarciowego szczęki,

- weryfikacja i korekta (w razie potrzeby) pozycji pierwszych zębów trzonowych, które są automatycznie umieszczane w najniższym punkcie wyrostka,

- zaznaczanie punktów na wale wzornika zwarciowego, aby określić pozycję dystalnej powierzchni drugich trzonowców,

- określenie kształtu i długości wału wzornika zwarciowego szczęki,

- badanie, potwierdzenie lub korekta wcześniej wskazanych linii i punktów na obu modelach,

- wybór kształtu i rozmiaru zęba z wirtualnej biblioteki,

- dostawienie zębów trzonowych (możliwe usunięcie lub wprowadzenie drugich zębów trzonowych w zależności od stanu jamy ustnej),

- dostawienie zębów przednich i weryfikacja ich położenia zgodnie z płaszczyzną zwarciową (możliwa modyfikacja),

- określenie stosunku pomiędzy górnymi i dolnymi zębami używając ,modelu łańcuchowego" do zmiany ich położenia na wzorniku zwarciowym,

- planowanie kierunku toru wprowadzenia 
plan is based on an analysis of the baseline and proportions of the face and teeth, described as a so-called "smile frame". The resulting temporary mock-ups, photos, and videos help doctors visualize the future prosthetic restoration, taking into account the red and white esthetics and the patient's individual facial features. An individualized approach to the patient's appearance is important. Using the patient's extraoral photographs and 2D or 3D images, the dental technician can select the appropriate shape of artificial teeth from the software library, modify it by individual tooth rotation, characterization and plan the appropriate occlusion scheme. Assembling the virtual teeth takes much less time than the conventional technique. The software allows the teeth to be combined into blocks and modified, or each tooth can be set independently. In addition, the mucosa can be characterized separately. This allows a better adaptation of the prosthesis to the patient's face (dentition types and constitutional theory according to E. Kretschmer) and ensures a good esthetic effect. By using a virtual articulator to produce a digital system, static and dynamic occlusion can be controlled, obtaining better functional parameters for a specific occlusion concept. The thickness of the prosthesis plates is also easy to control with the software and visually thanks to its translucency. ${ }^{1}$

However, it is still not possible to do a trial check of the dentures. This means that the patients can only see themselves in the new denture on a computer screen, provided that the patient's face is scanned first. According to the professional literature, it is possible to give the patient a denture to use already during the second visit. ${ }^{30}$

Digital dentures become a predictable and fast solution with a digital workflow. ${ }^{7}$ On the first visit, impressions are taken, then intermaxillary relationships are recorded and teeth are matched. On the second visit, the protezy przy użyciu techniki blokowania podcieni,

- określenie zakresu i cyfrowego modelowania końcowego kształtu i estetyki płyty protezy żuchwy i szczęki,

- scalanie zębów z płytą protezy i przygotowanie do frezowania.

W ostatnim czasie, bardzo często projektuje się uzupełnienie protetyczne w oparciu o protokół DSD (Digital Smile Design). Plan leczenia opiera się na analizie linii odniesienia oraz proporcji twarzy i zębów, opisanych jako tzw. „rama uśmiechu”. Powstałe tymczasowe makiety, zdjęcia i filmy pomagają lekarzom zwizualizować przyszłe uzupełnienie protetyczne z uwzględnieniem estetyki biało-czerwonej oraz indywidualnych cech twarzy pacjenta. Istotne jest indywidualne podejście do wyglądu pacjenta. Wykorzystując fotografie zewnątrzustne pacjenta oraz obrazy 2D lub 3D technik dentystyczny może dobrać odpowiedni kształt sztucznych zębów z biblioteki oprogramowania, zmodyfikować go poprzez indywidualną rotację zębów, charakteryzację oraz zaplanować odpowiedni schemat okluzji. Montaż wirtualnych zębów zajmuje znacznie mniej czasu niż w przypadku techniki konwencjonalnej. Oprogramowanie pozwala na łączenie zębów w bloki i ich modyfikację lub też ustawienie każdego zęba niezależnie. Dodatkowo, błonę śluzową można scharakteryzować oddzielnie. Pozwala to uzyskać lepsze dostosowanie protez do twarzy pacjenta (rodzaje uzębienia i teoria konstytucjonalna wg E. Kretschmera) oraz zapewnić dobry efekt estetyczny. Używając wirtualnego artykulatora do wytworzenia układu cyfrowego, można kontrolować okluzję statyczną i dynamiczną, uzyskując lepsze parametry czynnościowe dla określonej koncepcji okluzji. Grubość płyt protez jest również łatwa do kontrolowania za pomocą oprogramowania i wizualnie dzięki jej przezierności. ${ }^{1}$

Nadal jednak nie ma możliwości wykonania kontroli próbnych protez. Oznacza to, że 
finished complete dentures are delivered to the office. However, further software improvements are needed to process the $3 \mathrm{D}$ data. ${ }^{4,5}$

The advantages of digital fabrication of complete removable dentures include:

- fewer visits,

- reduced shrinkage of the acrylic plate due to grinding of the pre-polymerized acrylic resin and increased strength and fit of the denture,

- reduced denture fabrication time,

- reduced risk of prosthetic stomatopathy,

- advances in standardization of clinical trials for removable dentures,

- easy repetition of the denture fabrication due to archiving of stored data,

- better control of the quality of fabrication. ${ }^{15,29,31}$

However, digital fabrication of dentures has some limitations and disadvantages such as:

- difficulties in digital impression taking and recording of central occlusion, lip support, which until now must be done in conventional procedures,

- inability to define the occlusal plane,

- increased material and laboratory costs compared to conventional methods,

- inability to perform oral trial checks of dentures, which prevents patients and dentists from evaluating dentures before final fabrication. ${ }^{15,25}$

It is also worth noting that the use of CAD/ CAM technique is about $50 \%$ more expensive compared to the conventional technique. It requires the use of technically advanced equipment such as a 3D camera, software with the ability to download DICOM data, and devices to determine the plane of occlusion. It is hoped that costs will decrease in the future when the method is more widely used in clinical practice. ${ }^{25}$ pacjent widzi siebie w nowej protezie wyłącznie na ekranie komputera, pod warunkiem wcześniejszego zeskanowania twarzy pacjenta. Według fachowej literatury, możliwe jest oddanie pacjentowi protezy do użytkowania już podczas drugiej wizyty. ${ }^{30}$

Proteza cyfrowa staje się przewidywalnym i szybkim rozwiązaniem dzięki cyfrowemu przebiegowi pracy. ${ }^{7}$ Na pierwszej wizycie pobierane są wyciski, następnie rejestruje się relacje międzyszczękowe i dobiera się zęby. $\mathrm{Na}$ drugiej wizycie gotowe protezy całkowite są dostarczane do gabinetu. Jednak do przetwarzania danych 3D potrzebne są dalsze ulepszenia oprogramowania. ${ }^{4,5}$

Wśród zalet cyfrowego wykonania protez całkowitych wymienia się:

- mniejszą liczbę wizyt,

- ograniczony skurcz płyty akrylowej dzięki zmieleniu wstępnie spolimeryzowanej żywicy akrylowej oraz wzrost wytrzymałości i dopasowania protez,

- skrócony czas wykonania protezy,

- zmniejszenie ryzyka wystąienia stomatopatii protetycznej,

- postępy w standaryzacji badań klinicznych nad protezami ruchomymi,

- łatwe powtórzenie wykonania protezy dzięki archiwizacji zapisanych danych,

- lepszą kontrolę jakości wykonania. ${ }^{15,29,31}$

Cyfrowe wykonanie protez posiada jednak pewne ograniczenia i wady, takie jak:

- trudności w zakresie cyfrowego pobierania wycisku i rejestracji zwarcia centralnego, podparcia warg, które jak do tej pory muszą być wykonane w procedurach konwencjonalnych,

- brak możliwości zdefiniowania płaszczyzny zwarcia,

- zwiększone koszty materiałowe i laboratoryjne $\mathrm{w}$ porównaniu $\mathrm{z}$ kosztami metod konwencjonalnych,

- brak możliwości wykonania kontroli próbnych protez wjamie ustnej, co 


\section{Conclusion}

Complete removable dentures fabricated using dental CAD/CAM systems can be an alternative to the protocols of traditional fabrication of such restorations. uniemożliwia ocenę protez przez pacjentów i lekarzy stomatologów przed końcowym wykonaniem protezy. ${ }^{15,25}$

Warto też zauważyć, że zastosowanie techniki CAD/CAM jest około $50 \%$ droższe w porównaniu z techniką konwencjonalną. Wymaga użycia zaawansowanego technicznie sprzętu, takiego jak kamera 3D, oprogramowanie z możliwością pobrania danych DICOM oraz urządzenia do wyznaczania płaszczyzny okluzji. Należy mieć nadzieję, że w przyszłości koszty ulegną zmniejszeniu, gdy metoda będzie szerzej stosowana w praktyce klinicznej. ${ }^{25}$

\section{Wniosek}

Protezy całkowite wykonane z zastosowaniem stomatologicznych systemów CAD/CAM mogą stanowić alternatywę dla protokołów tradycyjnego wykonawstwa tego rodzaju uzupełnień protetycznych.

\section{References / Piśmiennictwo}

1. Contrepois M, Sireix Ch, Soenen A, Pia JP, Lasserre JF: Complete denture fabrication with CAD/CAM technology: a case report. Int J Esthet Dent 2018; 13: 66-85.

2. Paulino MR, Alves LR, Gurgel BCV, Calderon $P S$ : Simplified versus traditional techniques for complete denture fabrication: a systematic review. J Prostet Dent 2015; 113: 12-16. https:// doi.org/10.1016/j.prosdent.2014.08.004

3. Rodakowska E, Bagińska J, Jamiołkowski J, Cylwik-Rokicka D, Mierzyńska K, Fryc J: Skala Oceny Ogólnego Zdrowia Jamy Ustnej (GOHAI) u pacjentów użytkujących protezy całkowite. Gerontologia Polska 2017; 25: 112-117.

4. Felton DA: Complete edentulism and comorbid diseases: an update. J Prosthodont 2016; 25: 5-20. doi: 10.1111/jopr.12350
5. Han $W$, Li Y, Zhang $Y, L v Y, H u$, Liu H, Ma $Z$, Shen $Y$ : Design and fabrication of complete dentures using CAD/CAM technology. Medicine 2017; 96: 1, e5435. http://dx.doi. org/10.1097/MD.0000000000005435

6. Yilmaz B, Azak AN, Alp G, Eksi H: Use of $\mathrm{CAD} / \mathrm{CAM}$ technology for the fabrication of complete dentures: An alternative technique. J Prosthet Dent 2017; 118: 140-143. https://doi. org/10.1016/j.prosdent.2016.10.016

7. Chmielewski K, Ryncarz W, Ojc OY, Goncalves P, Baek K-W, Cok S, Dard M: Image analysis of immediate full-arch prosthetic rehabilitations guided by a digital workflow: assessment of the discrepancy between planning and execution. Int J Implant Dent 2019; 5: 26. https://doi.org/10.1186/s40729-019-0179-1

8. Srinivasan M, Gjengedal H, Cattani-Lorente 


\section{M, Moussa M, Durual S, Schimmel M, Müller}

$F$ : CAD/CAM milled complete removable dental prostheses: An in vitro evaluation of biocompatibility, mechanical properties, and surface roughness. Dent Mater J 2018; 37: 526-533. https://doi.org/10.4012/dmj.2017-207

9. Kawahata N, Ono H, Nishi Y, Hamano T, Nagaoka E: Trical of duplication procedure for complete denture by CAD/CAM. J Oral Rehabil 1997; 24: 540-548. https://doi.org/ 10.1111/j.1365-2842.1997.tb00371.x

10. Maeda Y, Minoura M, Tsutsumi S, Okada M, Nokubi TA: CAD/CAM system for removable denture. Part I: Fabrication of complete dentures. Int J Prosthodont 1994; 7: 17-21.

11. Baba NZ, AlRumaih HS, Goodscre BJ, Goodacre CJ: Current techniques in CAD/ CAM denture fabrication. Gen Dent 2016; 64: 23-28.

12. Bidra AS, Farrell K, Burnham D, Dhingra A, Taylor TD, Kuo CL: Prospective cohort pilot study of 2-visit CAD/CAM monolithic complete dentures and implantretained overdentures: Clinical and patientcentered outcomes. J Prosthet Dent 2016; 115: 578-586. https://doi.org/10.1016/j. prosdent.2015.10.023

13. Kattadiyil MT, Jekki R, Goodacre CJ, Baba NZ: Comparison of treatment outcomes in digital and conventional complete removable dental prosthesis fabrications in a predoctoral setting. J Prosthet Dent 2015; 114: 818-825. https://doi.org/10.1016/j. prosdent.2015.08.001

14. Pereyra NM, Marano J, Subramanian G, Quek $S$, Leff D: Comparison of patient satisfaction in the fabrication of conventional dentures vs. DENTCA (CAD/CAM) dentures: A case report. J N J Dent Assoc 2015; 86: 26-33.

15. Bilgin MS, Baytarogul EN, Erdem A, Dilber E: A review of computer-aided design/computeraided manufacture techniques for removable denture fabrication. Eur J Dent 2016; 10: 286291. doi: $10.4103 / 1305-7456.178304$
16. Sun Y, Lu P, Wang Y: Study on CAD\&RP for removable complete denture. Comput Methods Programs Biomed 2009; 93: 266-72. doi: 10.1016/j.cmpb.2008.10.003

17. Infante L, Yilmaz B, McGlumphy E, Finger I: Fabricating complete dentures with $\mathrm{CAD} /$ CAM technology. J Prosthet Dent 2014; 111: 351-355. https://doi.org/10.1016/j.prosdent. 2013.10.014

18. Bidra AS, Taylor TD, Agar JR: Computeraided technology for fabricating complete dentures: systematic review of historical background, current status, and future perspectives. J Prosthet Dent 2013; 109: 361-366. https://doi. org/10.1016/S0022-3913(13)60318-2

19. Goodacre CJ, Garbacea A, Naylor WP, Daher T, Marchack CB, Lowry J: CAD/ CAM fabricated complete dentures: concepts and clinical methods of obtaining required morphological data. J Prosthet Dent 2012; 107: 34-46. https://doi.org/10.1016/ S00223913(12)60015-8

20. Davidowitz G, Kotick PG: The use of CAD/ CAM In dentistry. Dent Clin North Am 2011; 55: 559-70, https://doi.org/10.1016/j. cden.2011.02.011

21. Kattadiyil MT, Goodacre CJ: CAD/CAM technology: application to complete dentures. J Loma Linda University Dentistry 2012; 23 : 16-23.

22. Van Noort $R$ : The future of dental devices is digital. Dent Mater 2012; 28: 3-12. https:// doi.org/10.1016/j.dental.2011.10.014

23. Bi Y, Wu S, Zhao Y, Bai S: A new metod for fabricating orbital prosthesis with CAD/CAM negative mold. J Prosthet Dent 2013; 110: 424-428. https://doi.org/10.1016/j.prosdent. 2013.05.003

24. Pascu N-E, Dobrescu T, Opran C, Enciu G: Realistic scenes in CAD application. Procedia Engineering 2014; 69: 304-309.

25. Sun YC, Lü PJ, Wang Y, Han JY, Zhao JJ: Research and development of computer aided design and rapid prototyping technology 
for complete denture. Zhonghua Kou Qiang Yi Xue Za Zhi 2007; 42: 324-329. Chinese. PMID: 17888244.

26. Borracchini $A$, Fares $F$, Natile $G$, Ram $H$ : The cutting edge laboratory. Full denture made $100 \%$ with Zirkonzahn digital workflow. Labline Magazin VIII 2018: 52-59. ENLabline-2018-summer-web.pdf - Zirkonzahn.

27. Othman HI: Role of computer aided design and computer aided manufacturing technology in prosthetic implant restorations. Int J Dent Clin 2012; 4.

28. John AV, Abraham G, Alias A: Two visit CAD/ CAM milled dentures In the rehabilitation of edentulous arches: A case series. J Indian Prosthodont Soc 2019; 19: 88-92. doi: $10.4103 /$ jips.jips_252_18

29. Kanazawa M, Inokoshi $M$, Minakuchi S,
Ohbayashi N: Trial of CAD/CAM system for fabricating complete dentures. Dent Mater J 2011; 30: 93-96. https://doi.org/10.4012/ dmj.2010-112

30. Bidra AS: The 2-visit CAD-CAM implant-retained overdenture: a clinical report. J Oral Implantol 2014; 40: 722-728. https://doi. org/10.1563/AAID-JOI-D-12-00237

31. Sirirungrojying $S$, Srisintorn $S$, Akkayanont P: Psychometric profiles of temporomandibular disorder patients in southern Thailand. J Oral Rehabil 1998; 25: 541-544. https://doi. org/10.1046/j.1365-2842.1998.00298

Zaakceptowano do druku: 17.11.2021 r.

Adres autorów: 15-276 Białystok, ul. M. Skłodowskiej-Curie 24.

C Zarząd Główny PTS 2021. 